
disease $(n=55)$ or ulcerative colitis $(n=40)$ and in controls $(n=30)$

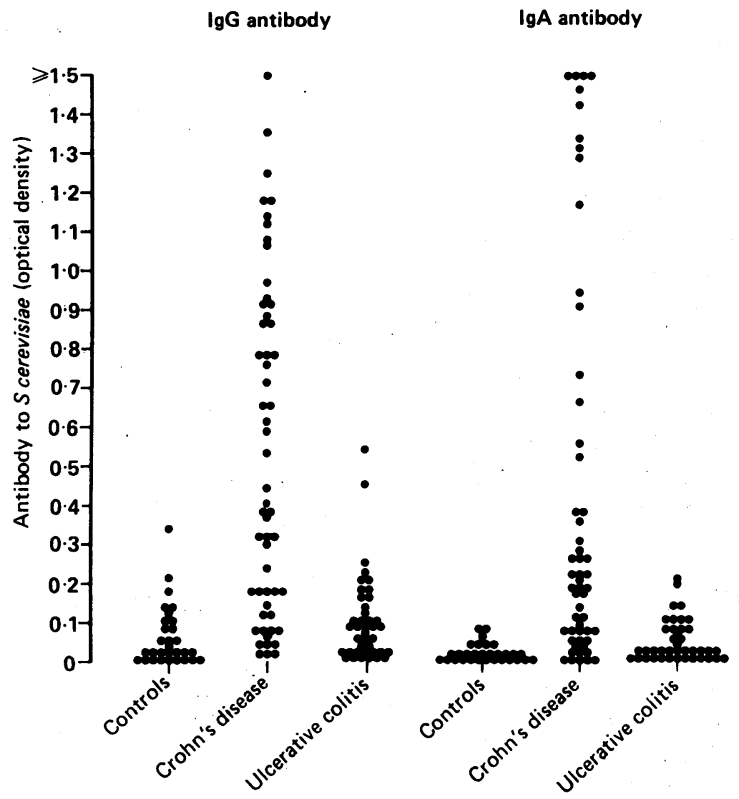

patients. ${ }^{5}$ More probably, Crohn's disease results from hypersensitivity to $S$ cerevisiae antigens, and this would be consistent with the responsiveness of Crohn's disease to steroid treatment and bowel rest. Another possibility is infection by an unknown agent that cross reacts antigenically with $S$ cerevisiae. Further investigation of the yeast antigens and their potential cross reaction is required.

Strains of $S$ cerevisiae are used in baking and brewing and are found in a wide variety of foodstuffs. A controlled trial of a yeast free diet for patients with Crohn's disease may therefore be worth while. We intend to investigate patients with other diarrhoeal diseases, including coeliac disease, to establish the specificity of antibody to $S$ cerevisiae as a marker for Crohn's disease; our results indicate that it may be valuable in distinguishing Crohn's disease from ulcerative colitis.

This work was supported by research grants from the Scottish Home and Health Department. We are grateful to the blood transfusion service for supplying blood donor serum.

1 Paganelli R, Pallone F, Montano S, et al. Isotypic analysis of antibody response to a food antigen in inflammatory bowel disease. Int Arch Allergy Appl Immunol 1985;78:81-5.

2 Knoflach P, Park BH, Cunningham R, Weiser MM, Albini B. Serum antibodies to cow's milk proteins in ulcerative colitis and Crohn's disease. Gastroenterology 1987;92:479-85.

3 Clamp SE, Myren J, Bouchier IAD, Watkinson G, de Dombal FT. Diagnosis of inflammatory bowel disease: an international multicentre scoring system. BrMed f 1982;284:91-5.

4 Snedecor GW, Cochran WG. Statistical methods. 6th ed. Iowa: Iowa State University Press, 1967:131.

5 Eng RHK, Drehmel R, Smith SM, Goldstein EJC. Saccharomyces cerevisiae infections in man. Sabouraudia 1984;22:403-7.

(Accepted 28 fune 1988)

\section{Rupture of tendon after cryotherapy for hand wart}

\section{Victoria M Yates, $M$ M Scott, Elizabeth D Carter}

Blackburn Royal Infirmary, Blackburn BB2 8LR Victoria M Yates, MRCP consultant dermatologist M M Scott, FRCS, consultant orthopaedic surgeon Elizabeth D Carter, $\mathbf{M B}$, clinical assistant

Correspondence to: Dr Yates.

We describe a patient who developed necrosis of the central slip of the extensor tendon of her right little finger after cryotherapy for a viral wart overlying the proximal interphalangeal joint.

\section{Case report}

A 25 year old woman was referred for cryotherapy for a large wart over the proximal interphalangeal joint of her right little finger after treatment with topical
Boutonnière deformity with hyperextension of distal phalanx resulting from cryotherapy for wart on proximal interphalangeal join salicylic acid had failed. Liquid nitrogen was applied to the wart on three occasions at intervals of six weeks with a liquid nitrogen spray with a $C$ nozzle held $2 \mathrm{~cm}$ above the surface of the skin. The duration of freezing

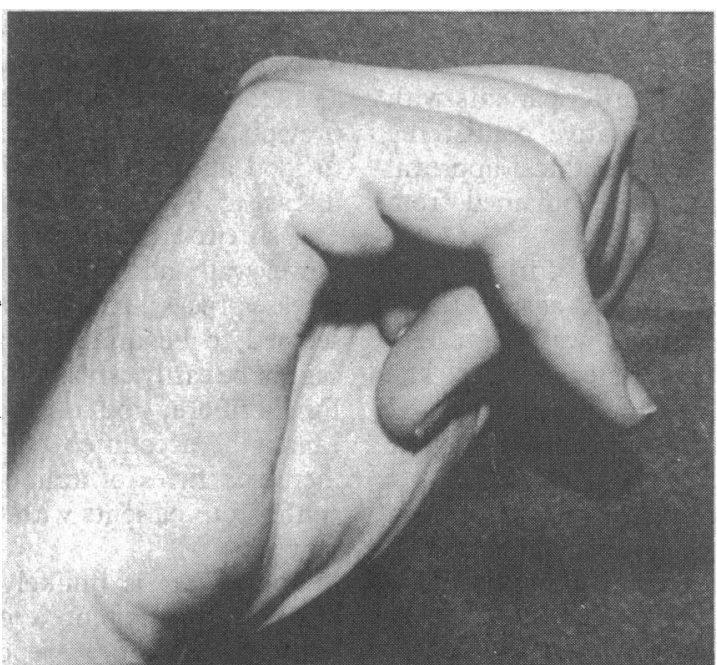

on each occasion was 10 seconds from the formation of ice. Twenty four hours after the third application of liquid nitrogen she noticed blistering of the skin over the treated area, and subsequently swelling and flexion occurred at the proximal interphalangeal joint. An $x$ ray film of the joint did not show infection, and the finger was treated with a dynamic splint. As the swelling subsided a boutonnière deformity of the finger was seen with hyperextension of the distal phalanx (figure), and it was obvious that the central slip of the extensor tendon had ruptured.

Surgical exploration showed a defect in the extensor expansion with sloughing of the central slip of the extensor tendon. The defect was corrected by a modified Littler procedure. The patient gradually regained partial function of the finger.

\section{Comment}

Blistering of the skin after cryotherapy is a common side effect, ${ }^{1}$ but to our knowledge tendon necrosis has not been reported before. Shepherd has shown that connective tissue is not affected by standard freeze times. ${ }^{2}$ Studies on the effects of cryosurgery on peripheral nerves have shown that even the delicate perineurium, which is largely made up of collagen, is unaffected by freezing. ${ }^{3}$ On the basis of this and other scientific evidence ${ }^{4}$ we did not expect tendon necrosis to occur. In view of this side effect and in the light of a recent report by Keefe and Dick, ${ }^{5}$ who suggested that cryotherapy should be delegated to nurses, we think that anyone treating lesions overlying tendons should exercise caution.

1 Zacarian SA, ed. Cryosurgery for skin cancer and cutaneous disorders. St Louis: Mosby, 1985:286.

2 Shepherd J. The effects of low temperature on dermal connective tissue components. Oxford: Oxford University, 1979. (MSc Dissertation.)

3 Barnard D. The effects of extreme cold on sensory nerves. Ann R Coll Surg Engl 1980;62:180-7.

4 Dawber R. Cold kills! Clin Exp Dermatol 1988;13:137-50.

5 Keefe M, Dick DC. Dermatologists should not be concerned in routine treatment of warts. $\mathrm{Br}$ Med f 1988;296:177-9. 